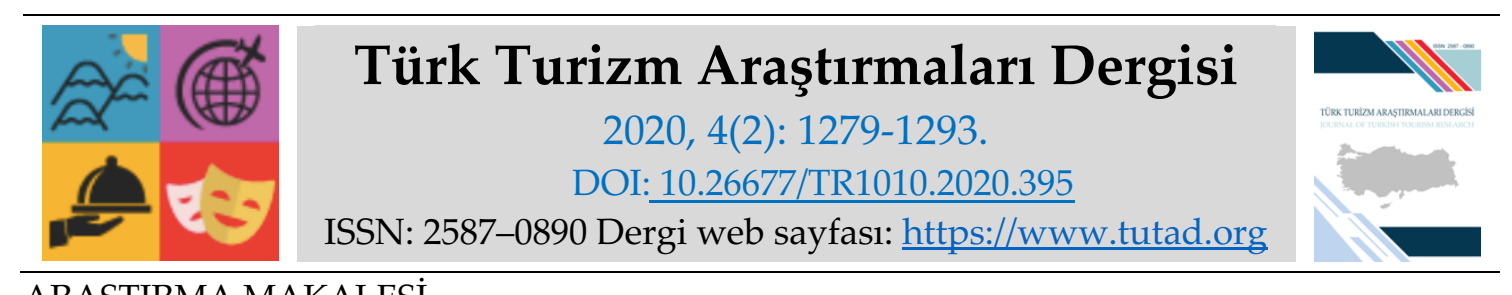

ARAŞTIRMA MAKALESI

\title{
Müşteri Vatandaşlık Davranışı Ölçeğinin Geçerlilik ve Güvenilirlik Çalışması
}

Dr. Öğr. Üyesi Ülker ERDOĞAN ARACI, Batman Üniversitesi, Hasankeyf Meslek Yüksekokulu, Batman, e-posta: ulker.erdogan@batman.edu.tr ORCID: https://orcid.org/0000-0001-8244-5190

Dr. Öğr. Üyesi Emrah Köksal SEZGIN, Adnan Menderes Üniversitesi, Davutlar Meslek Yüksekokulu, Aydın, e-posta: ekoksalsezgin@adu.edu.tr ORCID: https://orcid.org/0000-0003-3165-7147

Öz

Bu araştırmanın amacı, Yi ve Gong (2013) tarafından geliştirilen Müşteri Vatandaşlık Davranışı Ölçeğinin Türkçe versiyonunun gerçerlilik ve güvenilirlik analizlerini gerçekleştirmektir. Bu çalışmada müşteri vatandaşlık davranışı ölçeğinin Türkiye' de de yapı geçerliliği bağlamında test edilerek Türkçe'ye uyarlanması hedeflenmiştir. Araştırmanın örneklemi, İzmir ili 1. Sınıf restoran işletmelerinden hizmet satın alan 435 müşteriden oluşmaktadır. Veri setinin analizinde keşfedici ve doğrulayıcı faktör analizinden yararlanılmıştır. Keşfedici faktör analizi sonuçlarına göre, her bir maddenin faktör yükü .60'ın üzerindedir. Kaiser-Meyer-Olkin değeri .792, Bartlett Küresellik Testi için Ki-Kare: 2943,910, p değeri: ,000. olarak tespit edilmiştir. Özdeğerleri birin üzerinde olan 4 faktör, toplam varyansın .67.674'ünü açıklamaktadır. Cronbach's Alpha (güvenilirlik katsayısı) değeri ise .825 olarak hesaplanmıştır. Doğrulayıcı faktör analizi sonuçlarına göre ise, uyum iyiliği kriterleri çerçevesinde, modeldeki ilişkilerin örneklem verisi ile iyi derecede tutarlı olduğu bulunmuştur (Ki-Kare Uyum Testi (x2/sd) değeri; 2,91, CFI=0,94, NFI=0,92, RMSA=0,07, GFI= 0,94, AGFI= 0,91). AVE skorları 0,55 ile 0,78 arasında, bütünleşik güvenilirlik değerleri ise 0,81 ile 0,91 arasındadır. Ayrıca araştırma bulgularına göre, müşteriler sırasıyla en çok restoranı tavsiye etme ve restorana geribildirim sağlama davranışı göstermekte, daha sonra diğer müşterilere yardım etme, en az ise restoranı tolere etme davranışında bulunmaktadır. Yi ve Gong (2013) tarafından geliştirilmiş müşteri vatandaşlık davranışı ölçeğinin, İzmir ili 1. Sınıf restoran müşterileri örnekleminde, geçerlilik ve güvenilirliği test edilmiş, orjinal ölçek veri seti ile incelenmiş ve ölçeğin geçerli ve güvenilir olduğu tespit edilmiştir.

Anahtar Kelimeler: Müşteri Vatandaşlık Davranışı, Restoran Müşterileri, Geçerlilik, Güvenilirlik. Makale Gönderme Tarihi: 23.12.2019

Makale Kabul Tarihi: 09.04.2020

\section{Önerilen Atıf:}

Erdoğan Aracı, Ü. ve Sezgin, E. K. (2020). Müşteri Vatandaşlık Davranışı Ölçeğinin Geçerlilik ve Güvenilirlik Çalışması, Türk Turizm Araştırmaları Dergisi, 4(2): 1279-1293.

(C) 2020 Türk Turizm Araştırmaları Dergisi. 


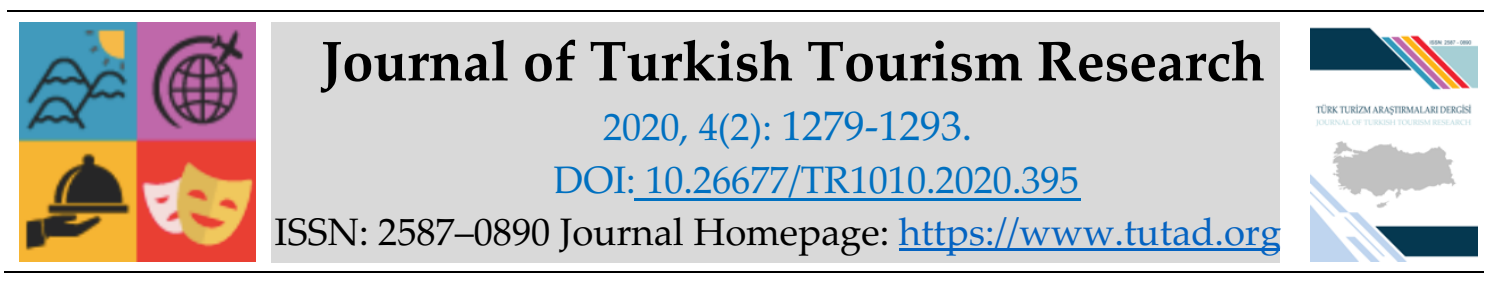

RESEARCH PAPER

\title{
The Study of Validity and Reliability of Customer Citizenship Behavior Scale
}

Assistant Prof. Dr. Ülker ERDOĞAN ARACI, Batman University, Hasankeyf Vocational School, Batman, e-mail: ulker.erdogan@batman.edu.tr ORCID: https://orcid.org/0000-0001-8244-5190

Assistant Prof. Dr. Emrah Köksal SEZGIN, Adnan Menderes University, Davutlar Vocational School, Aydın, e-mail: ekoksalsezgin@adu.edu.tr

ORCID: https://orcid.org/0000-0003-3165-7147

\begin{abstract}
The aim of this research is to perform the validity and reliability analyzes of the Turkish version of the Customer Citizenship Behavior Scale which is developed by Yi and Gong (2013). This study tested the validity of customer citizenship behavior scale in the context of the structure in Turkey is aimed to be adapted into Turkish. The sample of the study consists of 435 customers who purchased services from the 1st Class restaurant establishments in İzmir. In the analysis of the data set, exploratory and confirmatory factor analysis was used. According to the exploratory factor analysis results, the factor load of each item is over .60, The Kaiser-Meyer-Olkin Measure of sampling adequacy was .792 and the Bartlett's Test of Sphericity was 2943,910 $(\mathrm{p}<.000)$. All factors with eigenvalues above one together explained $67.674 \%$ of the total variance. Cronbach's Alpha (coefficient of reliability) was calculated as .825 . According to the confirmatory factor analysis results, within the framework of goodness of fit criteria, the relationships in the model were found to be well consistent with the sample data (Chi-Square Fit Test (x2 / sd) value; 2.91, CFI $=0.94, \mathrm{NFI}=0.92$, RMSA $=0.07$ GFI $=0.94$, AGFI $=0.91$ ). AVE scores are between 0.55 and 0.78 and composite reliability values are between 0.81 and 0.91 . According to the findings of the research, customers show the behavior of recommending and providing feedback to the restaurant, then helping other customers and at least tolerating the restaurant. The validity and reliability of the customer citizenship behavior scale which is developed by Yi and Gong (2013), was tested in the 1st class restaurant customers sample of İzmir province, examined the original scale with data set and the scale is found to be valid and reliable.
\end{abstract}

Keywords: Customer Citizenship Behavior, Restaurant Customers, Validity, Reliability.

Received: 23.12.2019

Accepted: 09.04.2020

Suggested Citation:

Erdoğan Aracl, Ü. and Sezgin, E. K. (2020). The Study of Validity and Reliability of Customer Citizenship Behavior Scale, Journal of Turkish Tourism Research, 4(2): 1279-1293.

(c) 2020 Türk Turizm Araştırmaları Dergisi. 


\section{GİRIŞ}

Hizmet sektörünün yapısal özelliği dolayısıyla, işletme ile müşteri arasında kurulan güçlü bağ, işletme lehine çıktılar sağlaması açısından önemlidir. Berry (1995) hizmetlerin doğası gereği müşterinin işletmeye duyduğu güveni en güçlü pazarlama aracı olarak yorumlamaktadır. İşletmelerin pazarlama etkinlikleri pekçok değişken odağında şekillenmektedir. Bununla birlikte elde edilmeye çalışılan en önemli çıtılardan biri müşteri davranışları noktasında belirmektedir.

Müşteri vatandaşlık davranışı, pazarlama ve müşteri davranışları literatüründe yer alan nispeten yeni bir kavramdır (Balaji, 2014). Müşteri vatandaşlık davranışının hizmet sürecinde kritik bir role sahip olmasına rağmen (Yi vd., 2013), araştırmaların çoğu, müşterilerden çok çalışan davranışları üzerinde yoğunlaşmaktadır (Yoon ve Suh, 2003; Chiaburu vd., 2011; Tang ve Tsaur, 2016). Müşterilerin organizasyon içerisinde insan kaynağ konumlandırıması, stratejik avantaj olarak müşterilerin etkili yönetimine dikkat çekmektedir (Lengnick-Hall, 1996; Bowen vd., 2000).

Hizmet sürecine dahil olan tüm müşteriler paylaşılan hizmet deneyiminin ortak yaratıcısı konumundadır. Fırsatçı davranışlara sahip diğer müşterilerin varlığı şüphesiz ki bir kişinin hizmet sürecinde yaşayacağı deneyimi doğrudan etkileyebilir (Liu ve Tsaur, 2014). Müşterinin gönüllü performansı sonucu ekstra rol davranışları olarak tanımlanan müşteri vatandaşlık davranışı, hizmet sunumu sırasında ve sonrasında müşterilerin işletme lehine yardım, destek, fedakarlık gibi fayda sağlayıcı davranışlarını ifade etmektedir (Keh ve Teo, 2001; Groth, 2005, Tung vd., 2017). Bu davranışlar diğer müşterilere yardım etme ve hizmete dair işletmeye yapıcı öneriler, geribildirimler sunma (Bettencourt, 1997), hizmet aksaklıklarına dair işletmeyi tolere etme (Yi ve Gong, 2013) ve işletmeyi başkalarına tavsiye etme (Groth, 2005) şekinde boyutlandırılmaktadır.

Bu araştırmanın amacı, Yi ve Gong (2013) tarafından geliştirilen Müşteri Vatandaşlık Davranışı Ölçeğinin Türkçe versiyonunun gerçerlilik ve güvenilirlik analizlerini gerçekleştirmek, 4 boyutlu yapıyı test etmek ve Türkçe uyarlamasının kullanılabilirliğini ortaya koymaktır. Elde edilen bulguların ilgili literatüre katkı sağlayacağı düşünülmektedir.

\section{KAVRAMSAL ÇERÇEVE}

Müşteri vatandaşlık davranışı, müşterinin ilişkide olduğu işletmeye dair gönüllülük esasına dayalı, normal rol davranışı üzerinde sahiplenici, korumacı, tavsiye edici bir dizi aktivitesini içeren faaliyetler olarak ifade edilmektedir. Müşterinin organizasyonel süreç içerisinde, "gönüllü" olarak, hizmete dair geribildirimde bulunması, hizmet inovasyonuna katkı sağlaması adına yapıcı önerileri ile işletmeyi tolere etme, işletmeyi tavsiye etme davranışları ve diğer müşterilere gerektiğinde yardım etme istekliliği gibi faktörler ilgili olgunun bileşenleri olarak değerlendirilmektedir (Bettencourt, 1997; Groth, 2005; Rosenbaum ve Massiah, 2007; Gilde vd., 2011).

Literatürde hizmet sağlayıcılar olarak çalışanların örgütsel etkililik sağlama adına gönüllük esasına dayalı ekstra rol davranışları olarak tanımlanan "örgütsel vatandaşlık davranışı" ile ilgili yapılmış pek çok çalışma mevcuttur (Podsakoff ve Mackenzie, 1994; Podsakoff vd., 2009; Yen ve Teng, 2013; Chow vd., 2015). İşletmenin paydaşlarından biri olarak çalışanların örgüte olan katkısı, yadsınamaz bir gerçek olarak geçmişten günümüze pek çok çalışmanın konusu olmuştur. İlgili çalışmalarda ortaya konan sonuçlar, yönetim ve pazarlama alanında önemli yaklaşımlara 1şık tutmuştur. Hizmet sağlayıcıların, işletme performansına ve müşteri memnuniyetine olan etkisi pek çok çalışmadan elde edilen stratejik tespitler olarak hem literatüre hem de sektöre önemli bildirimler sağlamaktadır (Koys, 2001; Bienstock vd., 2003; Castro vd., 2004). Çalışanın 
örgütsel vatandaşlık davranışının stratejik önemi yanında müşteri vatandaşlık davranışı da günümüz işletmeleri için kritik çıktılara sahiptir. Literatürde ilgili çalışmalar incelendiğinde; işletmeye geribildirimde bulunma, işletmeyi tavsiye etme, diğer müşterilere yardım etme ve işletmeyi tolere etme bileşenleri müşteri vatandaşlık davranışının boyutları olarak değerlendirilmektedir (Bettencourt, 1997; Groth, 2005; Rosenbaum ve Massiah, 2007; Gilde vd., 2011; Yi vd., 2013; Revilla-Camacho vd., 2015).

Müşterinin hizmete dair geribildirimi ile işletmeye sıradışı değer sağlaması (Bettencourt, 1997; Yi vd., 2011) hizmetten elde edilen çıktıların başarısına etki etmektedir (Wilson vd., 2012). Dikkat edilmesi gereken önemli ayrım, müşterinin sergilediği ekstra rol davranışının "gönüllük" esasına bağlı olmasıdır (Gruen, 1995). Hizmeti geliştirme ve daha iyi hizmet sunumunun sağlanması adına müşteriler tarafından yapılan geribildirimlerin, getirilen yapıcı önerilerin, işletme performansına ve dolayısıyla müşteri memnuniyetine etkisi yüksektir (Yi ve Gong, 2013). Müşteri, işletme ile ilişkide olduğu her an, hizmete dair pekçok olguyu değerlendirme gücüne sahiptir (Bettencourt, 1997). Müşteriden elde edilecek çıktıların değeri, işletme değerini oluşturmaktadır. Bu doğrultuda müşterinin sesinin duyulması ve müşteriye aktif bir şekilde işletmeye değer kattığının hissettirilmesi önemlidir. Müşterilerin gereksinimlerini ve taleplerini, işletmeden daha iyi bir şekilde tasarlayacak olan yine müşterinin kendisidir. Bu tasarımın değeri, ilgili önerilerin hizmet geliştirme sürecine dahil edilmesiyle ortaya çıkacaktır.

Müşterinin ekstra rol davranışı olarak pozitif tavsiye, potansiyel müşterilerde farkındalık yaratması açısından işletme değerine önemli bir katkıdır (East vd., 2001). Literatürde taraftarlık ya da ağızdan ağıza reklam olarakta tanımlanan tavsiye davranışı (Bontis vd., 2007), özellikle hizmet sektöründe diğer müşterilerin karar verme süreçlerinde güçlü bir etkiye sahiptir (Casalo vd., 2008). Müşterilerin olumlu deneyimlerini paylaşması, işletmelerin yeni müşteri edinme maliyetlerinin kısmen de olsa azalmasında etkilidir (Duman, 2018).

Bir müşterinin diğer bir müşteriye, herhangi bir karşılık beklemeden, gönüllü olarak "kısmi çalışan" gibi yardım etme davranışında bulunması (Mills ve Morris, 1986), müşteri vatandaşlık davranışının boyutlarından birini oluşturmaktadır (Groth, 2005; Yi ve Gong, 2013). Rosenbaum ve Massiah (2007) bazı müşterilerin empati yaparak, kendi zor deneyimlerini hatırladığını ve benzer zorluklar yaşayan diğer müşterilere yardımcı olma konusunda sorumluluk duyduğunu belirtmektedir. Bu çerçevede müşteri vatandaşlık davranışının çıktısı olarak beliren diğer müşterilere yardım etme gönüllülüğü, işletme ile müşteri arasında kurulmuş olan bağın doğrudan göstergesi olarak ifade edilebilir.

İşletmeyi tolere etme, müşteri vatandaşlık davranışının diğer bir boyutudur. Müşteri, hizmetin karşılanması esnasında bir takım gecikmelere maruz bırakıldığında ya da yiyecek, içecek ve ekipmanlarla ilgili talebinin karşılanmaması gibi beklentisine uymayan bir hizmet deneyimi yaşadığında nazik bir şekilde ve sabırla ortaya çıkan olumsuzlukların giderilmesini bekleyebilmektedir (Lengnick-Hall vd., 2000; Yi ve Gong, 2013; Khan ve Hussainy, 2017; Hoehle vd., 2018).

Literatürde müşteri vatandaşlık davranışı odağında geliştirilen ilk ölçeklerden biri Bettencourt (1997) tarafından Amerika'da market müşterileri üzerinde gerçekleştirilen, müşterinin gönüllü performansı şeklinde isimlendirilen, sadakat, işbirliği ve katılım olarak 3 boyut 17 ifadeden oluşan çalışmadır. Groth (2005) ise müşteri vatandaşlık davranışı ölçeğini; tavsiye, yardım ve geribildirim şeklinde 3 boyut ve her boyutta 4'er ifade şeklinde geliştirmiştir. Bove vd., (2009) tarafından, hizmet sektörü müşterileri (eczane, kuaför, hastane) üzerinde gerçekleştirilen bir çalışmada, müşteri örgütsel vatandaşlık davranışı adı altında 8 boyut 29 ifadeden oluşan bir yapı ortaya koyulmuştur. Yi ve Gong (2013) tarafından geliştirilen müşteri vatandaşlık davranışı ölçeği, son 3 ayda çeşitli hizmet işletmelerinden (mağaza, restorant, kuaför, seyahat ve sağlık) 
hizmet satın alan 296 lisans ve yüksek lisans öğrencisi üzerinde gerçekleştirilmiştir. Bu araştırmanın da odak konusunu oluşturan ölçek 4 boyut ve 13 ifadeden oluşmaktadır.

\section{YÖNTEM}

Araştırmanın evrenini İzmir il ve ilçelerinde bulunan 1. sınıf restoranlardan hizmet satın alan müşteriler oluşturmaktadır. Bu çerçevede belirtilen işletmelerden hizmet satın alan 18 yaş üstü müşteriler araştırma evreni içerisinde yer almaktadır. Araştırma evreni olarak 1. sınıf restoranlar seçilmesinin nedeni, bu restoranların profesyonelleşme düzeylerinin daha fazla olmasıdır. Aynı zamanda araştırmaya 18 yaş üstü müşterilerin dahil edilmesinin nedeni ise, 12/06/1942 tarihli ve 5130 sayılı Resmi Gazetede yayınlanan 4250 numaralı İspirto ve İspirtolu İçkiler İnhisarı Kanunu'nun 6. maddesine göre bu müşterilerin ilgili restoranlardan herhangi bir kısıtlamaya maruz kalmadan yiyecek içecek hizmetinden faydalanmalarıdır.

Kültür ve Turizm Bakanlığı verilerinde, 16.05.2019 tarihli turizm işletme belgeli tesis sinıflandırmasında 34 adet 1 . sınıf restoran tespit edilmiştir. Bu işletmelerden hizmet satın alan müşteri sayısının tespitindeki zorluklar nedeniyle, ana kütlenin tam sayısı ortaya konamamıştır. Dolayısıyla ana kütleden örneklem seçilmesi yoluna gidilmiştir. Örneklem sayısının belirlenmesinde yapısal eşitlik modellemeleri için önerilen örneklem büyüklüğü kriterleri dikkate alınmıştır. Literatürde yer alan çalışmalar incelendiğinde, bazı araştırmacılar yapısal eşitlik modellerinde örneklem sayısının en az 200 olması gerektiğini belirtmektedir (Hair vd., 1998:605, Garver ve Mentzer, 1999:42). Bununla birlikte bazı araştırmacılar ise, örneklem büyüklügünün çalışmada kullanılan gözlenen değişken sayısının on katı olması gerektiğini ifade etmektedir (Hair vd., 1998:604; Grace, 2006:283; Hair vd., 2011:144; Kline, 2011:12).

Araştırmada olasılığa dayalı olmayan örnekleme yöntemlerinden yargısal örnekleme yöntemi ile seçilen 450 kişiden veriler anket yöntemi kullanılarak elde edilmiştir. Eksik ve hatalı doldurmadan kaynaklanan 15 anket değerlendirme dışı bırakılarak toplam 435 anket değerlendirmeye alınmıştır. Araştırmanın evrenindeki elemanların, örneklemde yer alma olasılığının bilinmediği durumlarda, yani evrenin sınırlarının bilinmediği durumlarda bu tip örneklemeler kullanılmaktadır. Olasılığa dayalı olmayan örneklemelerde, yansızlık kuralına uymak yerine araştırmanın amacına uygun özelliklere sahip kişilerin seçilmesi koşulu aranmaktadır. Araştırmacılar kendi yargılarını veya önceden edinmiş oldukları bilgilerini kullanarak örneklem belirlemekte yani araştırmanın amacına hizmet edecek kişileri seçmeyi tercih etmektedirler (Monette vd., 1990'dan akt Özen ve Gül, 2007: 412-414).

\section{Anket Formunun Düzenlenmesi}

Araştırmada, Yi ve Gong (2013) tarafından geliştirilen tavsiye (3 ifade) yardım etme (4 ifade) geribildirim sağlama ( 3 ifade) ve tolere etme ( 3 ifade) olmak üzere 13 ifade ve 4 boyuttan oluşan müşteri vatandaşlık davranışı ölçeği kullanılmıştır. Ölçeğin özgün formu, yedi basamaklı Likert tipi (1-Hiç katılmıyorum, 7-Tamamen katıllyorum) bir ölçektir. Bu çalışmada ölçeğin Türkçe formu 5'li Likert tipine göre hazırlanmıştır. Ölçekte yer alan ifadelerin Türkçe çevirisi iki dile de hakim alan uzmanları tarafından kontrol edilmiştir. Ölçme aracı Türkçe'ye uyarlandıktan sonra, pilot araştırma $(n=50)$ yapılarak anlaşılmayacak ifadeler tekrar gözden geçirilmiş ve gerekli düzeltmeler yapılmıştır. Aynı zamanda ankette, restoran müşterilerinin sosyo-demografik özelliklerini belirlemeye yönelik ifadelere de yer verilmiştir. 


\section{Veri Analizi ve Bulgular}

Araştırmada saha çalışması sonucu toplanan veriler öncelikle tanımlayıcı istatistikler çerçevesinde incelenmiştir. Verinin normal dağılıma uygunluğu basıklık ve çarpıklık değerleri ile ortaya konmuştur. Çalışmada kullanılan ölçme aracının, tekrarlanan ölçümlerde aynı sonucu verme derecesini belirlemek amacıyla güvenilirlik analizi uygulanmıştır. Araştırmada kullanılan ölçeğin geçerliliğini ortaya koymak amacıyla, keşfedici ve doğrulayıcı faktör analizi yapılmıştır. Araştırma verilerinin analizinde keşfedici faktör analizi için IBM SPSS 23 paket programından, doğrulayıcı faktör analizinin yapılmasında ise IBM AMOS 23 paket programından yararlanılmıştır.

Doğrulayıcı faktör analizi ile gözlenen değişkenlerin, bağlı oldukları gizil yapıların birer temsilcisi olup olmadığını ortaya koyabilmek amacıyla yakınsak ve ayrışma geçerliliği kullanılmıştır. Çalışmada kullanılan gizil değişken müşteri vatandaşlık davranışı boyutları kapsamında; tavsiye etme, tolere etme, yardım etme ve geribildirim faktörlerinden oluşmaktadır. Bu çerçevede öncelikle gizil değişkeni ölçen gözlenen değişkenlerin ilişki derecesini gösteren yakınsak geçerlilik, daha sonra her bir boyutun birbirinden ayrı yapılar olduğunu, yani farklı bir özelliği ölçtüğünü belirlemek amacıyla ayrışma geçerliliği kullanılmıştır (Bagozzi vd., 1991).

Yakınsak geçerlilik çerçevesinde kullanılan birleşik güvenilirlik değerleri (CR), ve açılanan ortalama varyans (AVE) değerleri önemlidir. Açıklanan ortalama varyans her bir gizil değişkenin gözlenen değişkenlerde açıkladığı toplam varyans değerini göstermektedir. Eğer gözlenen değişkenler, gizil değişkeni doğru olarak yansitıyor ise, AVE değerleri yüksek çıkmaktadır (\%50'den büyük). Birleşik güvenilirlik değeri ise, cronbach alfa değerine benzer şekilde hesaplanmakta ve gizil değişkene yüklenen gözlenen değişkenlerin içsel güvenilirliğini göstermektedir (Hair vd., 1998:612).

Ayrışma geçerliliğinin sağlanabilmesi için ise, bir gizil değişkene ait AVE değerinin karekökünün, o değişkenin diğer değişkenlerle olan korelasyon değerlerinden büyük olması gerekmektedir (Hair vd., 1998:612). Ayrıca yapının bir bütün olarak kabul edilebilir olması için yani boyutlara ait yapı geçerliliği için modeldeki ilişkilerin o model için toplanmış veriler ile yani örneklem verisi ile tutarlı olması gerekmektedir (Hoyle, 1995). Bu çerçevede doğrulayıcı faktör analizi aracılığıyla yapının uyum iyiliği kriterleri ortaya konmuştur.

\section{Tanımlayıcı İstatistikler}

Katılımclara ait demografik verinin değerlendirilmesinde frekans analizinden yararlanılmıştır. Genel olarak bir değerlendirme yapıldığında katılımcıların çoğunun erkek (\%58,2), 30-39 yaş aralığında $(\% 38,4)$ ve üniversite eğitimine $(\% 52,6)$ sahip bireylerden oluştuğunu söylemek mümkündür. Gelir durumuna göre ise müşterilerin $\% 35,2$ si $4001-5000$ TL arası aylık gelire sahiptir (Tablo 1).

Müşterilerin işletmeye geribildirimde bulunmalarına ilişkin ortalama 3,18 $\pm 1,03$; işletmeyi tolere etmelerine ilişkin ortalama 2,53 $\pm 0,93$; diğer müşterilere yardım etmelerine ilişkin ortalama $2,89 \pm 0,82$; ve işletmeyi tavsiye etmelerine ilişkin ortalama 3,79 $\pm 0,66^{\prime}$ dır. Buna göre, araştırma veri seti çerçevesinde, müşteriler en çok işletmeyi tavsiye etme ve işletmeye geribildirimde bulunma davranışında bulunmaktadır. Ayrıca çarpıklık ve basıklık katsayılarından elde edilen çarpıklık ve basıklık katsayıları +3 ile -3 arasında olduğundan, veri setinin normal dağılıma uygun olduğu saptanmıştır (Tabachnick ve Fidell, 2013) (Tablo2). 
Tablo 1. Müşteri Profili

\begin{tabular}{|c|c|c|c|}
\hline \multicolumn{2}{|c|}{ Demografik Değişkenler } & \multirow{2}{*}{$\begin{array}{c}\mathbf{n} \\
182\end{array}$} & \multirow{2}{*}{$\begin{array}{c}\% \\
41,8\end{array}$} \\
\hline Cinsiyet & Kadın & & \\
\hline & Erkek & 253 & 58,2 \\
\hline \multirow[t]{4}{*}{ Yaş } & $18-29$ & 130 & 29,9 \\
\hline & $30-39$ & 167 & 38,4 \\
\hline & $40-49$ & 113 & 26,0 \\
\hline & 50 ve üstü & 25 & 5,7 \\
\hline \multirow[t]{5}{*}{ Eğitim } & İlkokul & 22 & 5,1 \\
\hline & Ortaokul & 39 & 9,0 \\
\hline & Lise & 127 & 29,2 \\
\hline & Üniversite & 229 & 52,6 \\
\hline & Lisansüstü & 18 & 4,1 \\
\hline \multirow[t]{4}{*}{ Gelir } & 2000-3000 TL & 56 & 12,9 \\
\hline & 3001-4000 TL & 98 & 22,5 \\
\hline & 4001-5000 TL & 153 & 35,2 \\
\hline & 5000 TL ve üstü & 128 & 29,4 \\
\hline
\end{tabular}

Tablo 2. Ortalama ve Normal Dağılım İstatistiği

\begin{tabular}{lccccccc}
\hline & $\mathrm{n}$ & Minimum & Maximum & Ortalama & ss & Çarpıklık & Basıklı \\
\hline Yardım & 435 & 1,00 & 5,00 & 2,89 & 0,82 &, 212 &,- 136 \\
\hline Tolere & 435 & 1,00 & 5,00 & 2,53 & 0,93 &,- 009 &,- 823 \\
\hline Tavsiye & 435 & 1,00 & 5,00 & 3,79 & 0,66 &,- 617 &, 936 \\
\hline Geribildirim & 435 & 1,00 & 5,00 & 3,18 & 1,03 &,- 101 &,- 862 \\
\hline
\end{tabular}

Keşfedici faktör analizine dair tespit edilen faktör yükleri, özdeğerleri ve açılanan varyans değerleri, not kısmında belirtilen diğer değerlerle birlikte Tablo 3'de gösterilmektedir. Faktör 
analizinde temel bileşenler analizi ve direct oblimin döndürme yöntemi kullanılmıştır. Eğik döndürme yöntemi, araştırmacılar tarafından faktörler arasında ilişki olacağı düşünüldüğünde kullanılmaktadır (Çokluk, Şekercioğlu ve Büyüköztürk, 2012: 200). Bu araştırmada da faktörler arasında ilişki olabileceği düşünüldügü için direct oblimin eğik döndürme yöntemi tercih edilmiştir. Ölçekte yer alan her bir madde, faktörün ölçtüğü kavramsal yapıyla ilgilidir. Buna göre, her bir maddenin faktör yükü ,60'ın üzerindedir. KMO testi değişkenler arasındaki korelasyonları ve faktör analizinin uygunluğunu ölçen testtir. KMO testinin değeri 0 ile 1 aralığında olmalıdır. Bu çerçevede ölçeğin KMO değeri ,792 olarak tespit edilmiştir. Her bir maddenin özdeğeri (eigenvalue) 1'den büyük olan toplam 4 faktörden oluşan ve toplam varyansın \%67,674'ünü açıklayan bir yapıda olduğu görülmektedir. Açıklanan toplam varyans ,50'nin üzerindedir. Kısacası oluşturulan faktör yapısı toplam değişken varyansının yarısından fazlasını açıklamaktadır. Ayrıca ölçeğe ilişkin elde edilen Cronbach's Alpha (güvenilirlik katsayısı) değerine bakıldığında müşteri vatandaşlık davranışı ölçeğinin oldukça yüksek düzeyde bir güvenirlik katsayısına sahip olduğu ortaya çıkmıştır $(\alpha=, 825)$. Güvenilirlik analizi ilk olarak her faktör için ayrı ayrı uygulanmış daha sonra da bütüne bakılmıştır. Buna göre ölçeğin istatistik tutumlarının belirlenmesinde güvenirlik düzeyi yüksek ölçme sonuçlarının elde edilebileceği söylenebilir (Yaşlığlu, 2017).

\section{Geçerlilik ve Güvenilirlik}

Yapının geçerliliğini ölçmek için, 1. Sınıf restoran müşterilerinden toplanan verilere doğrulayıcı faktör analizi (DFA) yapılmıştır. DFA ile modeldeki değişkenlerin yakınsak geçerlilikleri (convergent validity) ölçülmüştür. Faktör yükleri, bütünleşik güvenilirlik (CR) (composite reliability), açıklanan ortalama varyans (AVE) değerleri yakınsak geçerliliği doğrulamaktadır. Modelin testinde faktör yükleri, bütünleşik güvenilirliği, açıklanan ortalama varyans, yakınsak geçerlilikleri ve ayrışma geçerlilik değerleri kullanılmıştır.

Tablo 4'te müşteri vatandaşlık davranışı boyutlarına ilişkin açıklanan ortalama varyans (AVE), bütünleşik güvenilirlik $(C R)$ ve faktör yükleri gösterilmiştir. Sonuçlar, kabul edilebilen ya da kabul değerlerinin daha üzerinde çıkmıştır. AVE skorları 0,55 ile 0,78 arasındadır. Bu değerler kabul edilen 0,50 değerinin üzerindedir (Fornell ve Larcker, 1981). Bütünleşik güvenilirlik değerleri 0,81 ile 0,91 arasındadır ve önerilen 0,70 değerinin üstünde olduğu görülmektedir (Bagozzi ve Yi, 1988).

Tablo 4'te ayrıca gözlenen değişkenlerle gizli değişkenlerin arasındaki ilişkiyi ifade eden faktör yükleri verilmiştir. Çalışmada elde edilen değerler tavsiye edilen eşik değeri 0,50' den yüksektir. (Hair vd., 1998). Bu da gözlemlenebilen değişkenlerdeki değişimin, gizli değişkendeki değişimi açıklayıcı özelliğinin göstergesidir

Ayrışma geçerliliği (discriminant) analizi ile müşteri vatandaşlık davranışı boyutlarını oluşturan her değişken ayrı olarak analiz edilmiştir. Bu analizle modelde kullanılan her değişkenin AVE'sinin karekök değerleri diğer değişkenlerin korelasyonları ile karşılaştırılmıştır. Burada AVE karekök değerleri diğer değişkenlerin korelasyonlarından daha büyük olması tavsiye edilmektedir (Chin, 1998). Değişkenlerin birbirleriyle korelasyonları ve AVE karekök değerleri koyu renkli olarak Tablo 5'te gösterilmiştir. Elde edilen bulgulara göre matrisin ana köşegen dışındaki sonuçları (değişkenlerin korelasyonları) ana köşegen değerlerinden (AVE karekök değerleri) az ya da eşit olması gerekmektedir. Bu nedenle ayrışma geçerliliğinde bir sorun olmadığı görülmektedir. 
Tablo 3. Keşfedici Faktör Analizi

\begin{tabular}{|c|c|c|c|c|}
\hline Faktörler & Faktör Yükleri & Özdeğer & $\begin{array}{c}\text { Açıklanan Varyans } \\
\%\end{array}$ & $\begin{array}{l}\text { Cronbach's } \\
\text { Alpha }\end{array}$ \\
\hline YARDIM ETME & & 3,870 & 29,766 & 805 \\
\hline $\begin{array}{l}\text { 1.Diğer müşteriler desteğime ihtiyaç } \\
\text { duyduğunda, onlara yardım ederim. }\end{array}$ & 676 & & & \\
\hline $\begin{array}{l}\text { 2.Bu rest.da müşterilerin problem } \\
\text { yaşadığını gördüğümde, onlara } \\
\text { yardım ederim. }\end{array}$ & 812 & & & \\
\hline $\begin{array}{l}\text { 3.Bu rest.da sağlanan hizmetler ile } \\
\text { ilgilidiğer müşterileri bilgilendiririm. }\end{array}$ & 684 & & & \\
\hline $\begin{array}{l}\text { 4.Diğer müşterilere tavsiyede } \\
\text { bulunurum. }\end{array}$ & 809 & & & \\
\hline TOLERE ETME & & 2,036 & 15,658 & 868 \\
\hline
\end{tabular}

5.Bu rest.da sağlanan hizmete dair yapılan hataları tolere edebilirim.

6.Bu rest.da talep ettiğim hizmet, normalden daha uzun sürede gerçekleştiğinde, bu restoranı tolere edebilirim.

7.Bu restoranda hizmetin beklentime

\begin{tabular}{|c|c|c|c|c|}
\hline TAVSIYYE ETME & & 1,696 & 13,048 & 751 \\
\hline 8.Bu restoranı herkese öneririm. &, 890 & & & \\
\hline $\begin{array}{l}\text { 9. Ailem ve arkadaşlarıma bu } \\
\text { restoranı tavsiye ederim. }\end{array}$ & 892 & & & \\
\hline $\begin{array}{l}\text { 10.Bu restorandan olumlu bir şekilde } \\
\text { bahsederim. }\end{array}$ & 636 & & & \\
\hline GERİBİLDİRIMM & & 1,196 & 9,202 & ,914 \\
\hline $\begin{array}{l}\text { 11.Bu rest. çalışanlarından iyi hizmet } \\
\text { aldığım zaman, bundan bahsederim. }\end{array}$ & ,764 & & & \\
\hline $\begin{array}{l}\text { 12.Bu restoranın hizmetine katkı } \\
\text { sağlayacak fikirlerimi restoran } \\
\text { çalışanlarıyla paylaşırım. }\end{array}$ & 648 & & & \\
\hline $\begin{array}{l}\text { 13.Bu rest.da karşılaştığım sorunları } \\
\text { çalışanlarla paylaşırım. }\end{array}$ & 780 & & & \\
\hline $\begin{array}{l}\text { Açılanan Toplam Varyans: \%67,674; } \\
\text { Testi için Ki-Kare: 2943,910; df: } 105 \text { p }\end{array}$ & $\begin{array}{l}\text { leyer- } \\
00 . \alpha=\end{array}$ & $\begin{array}{l}\text { em Yete } \\
\text { h's alfa }\end{array}$ & tlett Ki & \\
\hline
\end{tabular}


Tablo 4. Doğrulayıcı Faktör Analizi Sonuçları

\begin{tabular}{|c|c|c|c|c|c|}
\hline Boyut & Madde & Faktör Yükü & Ave & $\mathrm{Cr}$ & Cronbach's Alpha \\
\hline \multirow{5}{*}{ Yardım } & 1 & 681 & \multirow{5}{*}{0,55} & \multirow{5}{*}{0,83} & \multirow{5}{*}{805} \\
\hline & 2 & 789 & & & \\
\hline & & & & & \\
\hline & 3 & ,711 & & & \\
\hline & 4 & ,775 & & & \\
\hline \multirow{3}{*}{ Tolere } & 5 & 877 & \multirow{3}{*}{0,78} & \multirow{3}{*}{0,91} & \multirow{3}{*}{868} \\
\hline & 6 & 890 & & & \\
\hline & 7 & 877 & & & \\
\hline \multirow{3}{*}{ Tavsiye } & 8 & 843 & \multirow{3}{*}{0,60} & \multirow{3}{*}{0,81} & \multirow{3}{*}{,751 } \\
\hline & 9 & 863 & & & \\
\hline & 10 &, 579 & & & \\
\hline \multirow{3}{*}{ Geribildirim } & 11 & ,862 & \multirow{3}{*}{0,78} & \multirow{3}{*}{0,91} & \multirow{3}{*}{,914 } \\
\hline & 12 & 899 & & & \\
\hline & 13 & 879 & & & \\
\hline
\end{tabular}

Tablo 5. Müşteri Vatandaşlık Davranışı Boyutlarına İlişkin Ayrışma Geçerliliği

\begin{tabular}{lllll}
\hline Değişken & Yardım & Tolere & Tavsiye & Geribildirim \\
\hline Yardım & $\mathbf{0 , 7 4}$ & & & \\
\hline Tolere &, 231 & $\mathbf{0 , 8 8}$ & & \\
\hline Tavsiye &, 223 &, 078 & $\mathbf{0 , 7 7}$ & \\
\hline & & & & \\
Geribildirim &, 505 &, 084 &, 307 & $\mathbf{0 , 8 8}$ \\
\hline
\end{tabular}


Müşteri vatandaşlık davranışı ölçeğinin yapı geçerliliğini tespit etmek amacıyla uyum iyiliği değerleri Tablo 6'da gösterilmektedir. Buna göre; Ki-Kare Uyum Testi (x2/sd) değeri; 2,91, Karşılaştırmalı Uyum İndeksi (CFI) değeri; 0,94, Normlandırılmış Uyum İndeksi (NFI) Değeri; 0,92, Yaklaşık Hataların Ortalama Karekökü (RMSA); 0,07, Düzeltilmiş Uyum İyiliği İndeksi (AGFI) değeri; 0,91, Uyum İyiliği İndeksi (GFI); 0,94 olarak tespit edilmiştir. Buna göre, uyum iyiliği kriterleri çerçevesinde, modeldeki ilişkilerin örneklem verisi ile iyi derecede tutarlı olduğu söylenebilmektedir (Meydan ve Şeşen, 2011).

Tablo 6. Müşteri Vatandaşlık Davranışı Uyum İyiliği Değerleri

\begin{tabular}{lccc}
\hline Uyum İyiliği Kriterleri & $\begin{array}{c}\text { Uyum İyiliği } \\
\text { Değeri }\end{array}$ & $\begin{array}{c}\text { İyi Uyum } \\
\text { Şartı }\end{array}$ & $\begin{array}{c}\text { Kabul Edilebilir } \\
\text { Uyum Şartı }\end{array}$ \\
\hline Ki-Kare Uyum Testi (x2/sd) & $\mathbf{2 , 9 1}$ & $\leq 3$ & $\leq 5$ \\
\hline $\begin{array}{l}\text { Karşıllaştırmalı Uyum İndeksi (CFI) } \\
\text { Normlandırılmış Uyum İndeksi } \\
\text { (NFI) }\end{array}$ & $\mathbf{0 , 9 4}$ & $\geq 0,97$ & $\geq 0,90$ \\
\hline $\begin{array}{l}\text { Yaklaşı̈k Hataların Ortalama } \\
\text { Karekökü (RMSEA) }\end{array}$ & $\mathbf{0 , 0 7}$ & $\leq 0,95$ & $\geq 0,90$ \\
\hline $\begin{array}{l}\text { Düzeltilmiş Uyum İyiliği İndeksi } \\
\text { (AGFI) }\end{array}$ & $\mathbf{0 , 9 1}$ & $\geq 0,95$ & $\leq 0,08$ \\
\hline \begin{tabular}{l} 
Uyum İyiliği İndeksi (GFI); \\
\hline
\end{tabular} & $\mathbf{0 , 9 4}$ & $\geq 0,90$ & $\geq 0,85$ \\
\hline
\end{tabular}

\section{SONUÇ VE ÖNERILER}

Müşteri vatandaşlık davranışı, turizm endüstrisinin bileşenlerinden yiyecek içecek işletmelerinde, stratejik açıdan incelenmesi gerekli bir olgu olarak literatürde yerini almıştır. İşletmelerin yoğun rekabet ortamında sürdürülebilir kalkınmalarında, mevcut müşterileri kilit roller üstlenmektedir. Araştırmanın evrenini oluşturan restoran müşterilerinin, hizmet satın alma süreci ve sonrasında işletme lehine kendiliğinden oluşan vatandaşlık davranışları, pekçok açıdan işletmeye rekabet avantajı sağlamaktadır. Müşterilerin restoranda aldıkları hizmete dair geribildirimde bulunması, ilgili restoranın hizmet kalitesini arttırma çabasında kilit bir faktördür. Müşterilerin restoranda yaşadığı olumsuz deneyimleri tolere etmesi ise, işletmenin sahip olduğu sadık müşteri portföyü açısından bir gösterge niteliğindedir. Restoran içerisinde, bazı müşterilerin, diğer müşterilerin memnuniyetini sağlamadaki gönüllü davranışları ise, hizmet sektöründe, bir işletmenin diğer bir işletmeye karşı rekabet üstünlüğü sağlamada sahip olduğu en büyük fırsat olarak gözükmektedir. Sadık müşterilerin vatandaşlık davranışı, diğer müşterilerin dikkatini çekecektir. Duygusal ve sosyal açıdan değer ifade eden yardım davranışı ile diğer müşterilerin restorana dair farkındalıkları artacaktır. Hizmet sektöründe işletmeye dair en değerli tanıtım aracı, müşterilerdir. Restoranın tanınırlığını ve prestijini arttırmada pek çok yöntem söz konusu olabilirken, hizmete dair başka bir müşteriden diğer müşteriye gelen tavsiye davranışı, potansiyel müşterilerin restoran tercihlerinde çok daha etkili olacaktır. Bu kapsamda Yi ve Gong (2013) tarafından geliştirilmiş müşteri vatandaşlık davranışı ölçeğinin, İzmir ili 1. Sınıf 
restoran müşterileri örnekleminde, geçerlilik ve güvenilirliği test edilmiş, orjinal ölçek veri seti ile incelenmiştir.

Bu çalışmada müşteri vatandaşlık davranışı ölçeğinin Türkiye'de de yapı geçerliliği bağlamında test edilerek Türkçe' ye uyarlanması hedeflenmiştir. Öncelikle keşfedici faktör analizi yapılmış ve ölçeğin orijinaldeki gibi dört faktörlü olduğu görülmüştür. Dört boyutlu yapı toplam varyansın $\% 67,674$ 'ünü açıklamaktadır. Ölçek geliştirme ve uyarlama çalışmasında açıklanan varyans oranın \%30 ve üzeri ölçüt alındığı (Büyüköztürk, 2009: 124-125) göz önünde bulundurulduğunda, ölçeğin yapı geçerliğinin çok iyi bir düzeyde sağlandığı görülmektedir. Keşfedici faktör analizi sonucu elde edilen yapının, doğrulayıcı faktör analiziyle model uyumu test edilmiştir. Her iki faktör analizi sonucunda 13 madde ve dört faktörden oluşan ölçeğin, hem kuramsal hem de istatistiksel olarak uygun olduğu tespit edilmiştir.

Müşteri vatandaşlık davranışı ölçeğinin güvenirliğini belirlemeye yönelik iç tutarlık katsayısına bakılmıştır. Toplam iç tutarlılık katsayısının $\alpha=.825$ yardım etme boyutunun $\alpha=.805$, tolere etme boyutunun $\alpha=.868$, tavsiye etme boyutunun $\alpha=.751$ ve geribildirim boyutunun ise $\alpha=.914$ olduğu ve ölçeğin iç tutarlılığa sahip olduğu bulunmuştur. Buna göre müşteri vatandaşlık davranışı ölçeğinin Türkçe formunun kabul edilebilir değerlerde güvenilir ve geçerli bir ölçme aracı olduğu söylenebilir. Yi ve Gong (2013) tarafından geliştirilen ölçekte yer alan alt boyut "Yardım Etme, Tolere Etme, Tavsiye Etme ve Geribildirim" sayısı değişmemiştir. Araştırma sonuçları, ölçeğin orijinal yapısı ile tutarlı veriler gösterdiğine işaret etmektedir.

Müşterilerin vatandaşlık davranışına ilişkin elde edilen sonuçlar, restoran işletmelerinde farkındalık yaratması açısından önemlidir. Araştırma bulgularına göre, müşteriler sırasıyla en çok restoranı tavsiye etme ve restorana geribildirim sağlama davranışı göstermekte, daha sonra diğer müşterilere yardım etme, en az ise restoranı tolere etme davranışında bulunmaktadır. Araştırmadan tespit edilen sonuçlar doğrultusunda, aşağıdaki öneriler sunulabilir:

- Müşteriler üzerinde yapılacak olan çalışmalarda, müşteri vatandaşlık davranışı ölçeği kullanılarak geçerli ve güvenilir sonuçlar elde edilebilir.

- Restoran işletmeleri sahip olduğu müşteri profilini tanımalı ve onların davranışlarını izlemelidir.

- Restoranlarda müşterilerin vatandaşlık davranışını ortaya çıkaracak unsurlar belirlenmelidir.

- Müşterilerin restoranı tolere etme davranışlarının düşüklüğü sebebiyle geribildirimler titizlikle değerlendirilmelidir.

- Restoran işletmeleri, müşterilerinin sesini duymalıdır.

- Mevcut müşteriler korunmalıdır.

- Müşterilerle ömür boyu değer ilişkisi kurulmalıdır.

- Restoran işletmelerinde hizmetlere dair farkedilen ya da bildirilen aksaklıklar ivedi olarak giderilmeli ve benzer problemlerin tekrar yaşanmaması adına önlemler alınmalıdır.

Türkçe'ye uyarlaması yapılan bu ölçeğin geçerlilik ve güvenilirliğinin, daha farklı örneklem gruplarıyla test edilerek standartlaştırılması önemlidir. Gelecek çalışmalar için, müşteri vatandaşlık davranışı ölçeğinin turizm endüstrisinin diğer bileşenleri üzerinde incelenmesi önerilebilir. Ayrıca bağımlı değişken olarak restoran deneyimi, aracı değişken olarak güven ve bağımsız değişken olarak müşteri vatandaşlık davranışı arasındaki ilişkilerin incelendiği bir model önerilebilir. 


\section{KAYNAKÇA}

Bagozzi, R. and Yi, Y. (1988). On the Evaluation of Structural Equation Models, Journal of the Academy of Marketing Sciences, 16: 74-94.

Bagozzi, R., Yi, Y. and Philips, L. (1991). Assessing Construct Validity in Organisational Research, Administrative Science Quarterly, 36(3): 421-458.

Balaji, M. S. (2014). Managing Customer Citizenship Behavior: A Relationship Perspective, Journal of Strategic Marketing, 22(3): 222-239.

Bettencourt L. A. (1997). Customer Voluntary Performance: Customers as Partners in Service Delivery, Journal of Retailing, 73(3): 383-406.

Berry, L. L. (1995). Relationship Marketing of Services - Growing Interest, Emerging Perspectives, Journal of the Academy of Marketing Science, 23(4): 236-245.

Bienstock, C. C., DeMoranville, C. W. and Smith, R. K. (2003). Organizational Citizenship Behavior and Service Quality, Journal of Services Marketing, 17(4): 357-378.

Bontis, N., Booker, L. D. and Serenko, A. (2007). The Mediating Effect of Organizational Reputation on Customer Loyalty and Service Recommendation in the Banking Industry, Management Decision, 45(9): 1426-1445.

Bowen, D. E., Schneider, B. and Kim, S. S. (2000). Shaping Service Cultures Through Strategic Human Resource Management, (Editors) Swartz, T.A. and Iacobucci, D.: In Handbook of Services Marketing and Management (pp.439-454) Thousand Oaks, CA: Sage.

Bove, L. L., Pervan, S. J., Beatty, S. E. and Shiu, E. (2009). Service Worker Role in Encouraging Customer Organizational Citizenship Behaviors, Journal of Business Research, 62(7): 698-705.

Büyüköztürk, Ş. (2009). Sosyal Bilimler için Veri Analizi El Kitabı. (10. Basım). Ankara: Pegem Akademi.

Casalo, L.V., Flavián, C. and Guinalíu, M. (2008). The Role of Satisfaction and Website Usability in Developing Customer Loyalty and Positive Word-Ofmouth in the E-Banking Services, International Journal of Bank Marketing, 26(6): 399-417.

Castro, C. B., Armario, E. M. and Ruiz, D. M. (2004). The Influence of Employee Organizational Citizenship Behavior on Customer Loyalty, International Journal of Service Industry Management, 15(1): 27-53.

Chin, W. W. (1998). Issue and Opinions on Structural Equation Models with Unobservable Variables and Measuremente Error, Journal of Marketing Research, 18: 39-50.

Chow, C. W. C., Lai, J. Y. M. and Loi, R. (2015). Motivation of Travel Agents' Customer Service Behavior and Organizational Citizenship Behavior: The Role of Leader-Member Exchange and Internal Marketing Orientation, Tourism Management, 48: 362-369.

Chiaburu, D. S., Oh, I. S., Berry, C. M., Li, N. and Gardner, R. G. (2011). The Five-Factor Model of Personality Traits and Organizational Citizenship Behaviors: A Meta-Analysis, Journal of Applied Psychology, 96: 1140-1166.

Çokluk, Ö., Şekercioğlu, G. ve Büyüköztürk, Ş. (2012). Sosyal Bilimleri İçin Çok Değişkenli İstatistik SPSS ve LISREL Uygulamaları (2. baskı). Ankara: Pegem Akademi.

Duman, F. (2018). Kalite Yönetim Uygulamalarının Algısal Finansal Performans Üzerine Etkisi: Dört ve Beş Yıldızlı Otellerde Uygulama, Yönetim Bilimleri Dergisi, 16(31): 381-408. 
East, R., Lomax, W. and Narain, R. (2001). Customer Tenure, Recommendation and Switching, Journal of Consumer Satisfaction, Dissatisfaction and Complaining Behavior, 14: 46-54.

Fornell, C. and Larcker, F. D. (1981). Evaluating Structural Equation Models with Unobservable Variables and Measurement Error, Journal of Marketing Research, 18(1): 39-50.

Garver, M. S. and Mentzer, J. T. (1999). Logistics Research Methods: Employing Structural Equation Modelling to Test for Construct Validity, Journal of Business Logistics, 20, 33-57.

Gilde, C., Pace, S., Pervan, S. J. and Strong, C. (2011). Examining the Boundary Conditions of Customer Citizenship Behavior: A Focus on Consumption Ritual, Journal of Strategic Marketing, 19(7): 619-631.

Grace, J. B. (2006) Structural Equation Modeling and Natural Systems. New York: Cambridge University Press.

Groth, M. (2005). Customers as Good Soldiers: Examining Citizenship Behaviors in Internet Service Deliveries, Journal of Management, 31(1): 7-27.

Gruen, T. W. (1995). The Outcome Set of Relationship Marketing in Consumer Markets, International Business Review, 4(4): 447-69.

Hair, J. F., Anderson, R. E., Tatham, R. L. and Black, W. C. (1998). Multivariate Data Analysis. (Fifth Edition), New Jersey: Prentice-Hall Inc.

Hair F. J., Ringle C. M.and Sarstedt, M. (2011). PLS-SEM: Indeed, a Silver Bullet, Journal of Marketing Theory and Practice, 19(2): 139-151.

Hoehle, H., Aloysius, J. A., Walton, S. M. and Chan, F. (2018). Customers' Tolerance for Validation in Omnichannel Retail Stores Enabling Logistics and Supply Chain Analytics, The International Journal of Logistics Management, 29(2): 704-722.

Hoyle, R. (1995). The Structural Equation Modeling Approach: Basic Concepts and Fundamental Issues. (Editor) Hoyle, R.H.: In Structural Equation Modeling: Concepts, Issues, and Applications (pp. 115) Thousand Oaks CA: Sage.

Keh, H. T. and Teo, C. W. (2001). Retail Customers as Partial Employees in Service Provision: A Conceptual Framework, International Journal of Retail \& Distribution Management, 29(8): 370-378.

Khan, K. and Hussain, S. K. (2017). Dimensions of Customer Value Co-Creation Behavior in a Service Setting, Journal of Managerial Sciences, 11(3): 83-96.

Kline, R. B. (2011). Principles and Practice of Structural Equation Modeling. New York: The Guilford Press.

Koys, D. J. (2001). The Effects of Employee Satisfaction, Organizational Citizenship Behavior, and Turnover on Organizational Effectiveness: A Unit-Level, Longitudinal Study, Personnel Psychology, 54: 101-114.

Lengnick-Hall, C. A. (1996). Customer Contributions to Quality: A Different View of The Customer-Oriented Firm, The Academy of Management Review, 21(3): 791-824.

Lengnick-Hall, C. A., Claycomb, V. and Inks, L. W. (2000). From Recipient to Contributor: Examining Customer Roles and Experienced Outcomes, European Journal of Marketing, 34(3/4): 359-383.

Liu, J. S. and Tsaur, S. H. (2014). We Are in The Same Boat: Tourist Citizenship Behaviours, Tourism Management, 4: 88-100. 
Meydan, C. H. ve Şeşen, H. (2011). Yapısal Eşitlik Modellemesi Amos Uygulamaları.Ankara: Detay Yayıncilik.

Mills, P. K. and Morris, J. H. (1986). Clients as "Partial" Employees of Service Organizations: Role Development in Client Participation. The Academy of Management Review, 11(4): 726-735.

Özen, Y. ve Gül, A. (2007). Sosyal ve Eğitim Bilimleri Araştırmalarında Evren ve Örneklem Sorunu, Kazım Karabekir Eğitim Fakültesi Dergisi, 15: 394-422.

Podsakoff, E. M. and MacKenzie, S. B. (1994). Organizational Citizenship Behavior and Sales Unit Effectiveness, Journal of Marketing Research, 31: 351-363.

Podsakoff, N. P., Whiting, S. W., Podsakoff, P. M. and Blume, B. D. (2009). Individual- and Organizational-Level Consequences of Organizational Citizenship Behaviors: A Meta-Analysis, Journal of Applied Psychology, 94(1): 122-141.

Revilla-Camacho, M.Á., Vega-Vázquez, M. and Cossío-Silva, F. J. (2015). Customer participation and citizenship behavior effects on turnover intention, Journal of Business Research, 68(7): 16071611.

Rosenbaum M. S. and Massiah C. A. (2007). When Customers Receive Support from Other Customers: Exploring the Influence of Intercustomer Social Support on Customer Voluntary Performance, Journal of Service Research, 9(3): 257-70.

Tabachnick, B. G. and Fidell, L. S. (2013). Using Multivariate Statistics. (sixth ed.) Boston: Pearson.

Tang, Y. and Tsaur, S. (2016). Supervisory Support Climate and Service-Oriented Organizational Citizenship Behavior in Hospitality: The Role of Positive Group Affective Tone, International Journal of Contemporary Hospitality Management, 28(10): 2331-2349.

Tung, V. W. S., Chen, P. J. and Schuckert, M. (2017). Managing Customer Citizenship Behaviour: The Moderating Roles of Employee Responsiveness and Organizational Reassurance, Tourism Management, 59: 23-35.

Wilson, A., Zeithaml, V., Bitner, M. and Gremler, D. (2012). Services Marketing: Integrating Customer Focus Across the Firm. New York: McGraw Hill.

Yaşlığlu, M. M. (2017). Sosyal Bilimlerde Faktör Analizi ve Geçerlilik: Keşfedici ve Doğrulayıcı Faktör Analizlerinin Kullanılması, İstanbul Üniversitesi İşletme Fakültesi Dergisi, 46: 74-85.

Yen, C-H. and Teng, H.Y. (2013). The Effect of Centralization on Organizational Citizenship Behavior and Deviant Workplace Behavior in The Hospitality Industry, Tourism Management 36: 401-410.

Yi, Y. and Gong, T. (2013). Customer Value Co-Creation Behavior: Scale Development and Validation, Journal of Business Research, 66(9): 1279-1284.

Yi, Y., Gong, T. and Lee, H. (2013). The Impact of Other Customers on Customer Citizenship Behavior, Psychology \& Marketing, 30: 341- 356.

Yi, Y., Nataraajan, R. and Gong, T. (2011). Customer Participation and Citizenship Behavioral Influences on Employee Performance, Satisfaction, Commitment, and Turnover Intention, Journal of Business Research, 64(1): 87-95.

Yoon, M. H. and Suh, J. (2003). Organizational Citizenship Behaviors and Service Quality as External Effectiveness of Contact Employees, Journal of Business Research, 56(8): 597-611. 